\title{
REVIEW
}

\section{Effects of sewage pollution on coral-reef communities}

\author{
Robert A. Pastorok and Gordon R. Bilyard \\ Tetra Tech, Inc., 11820 Northup Way, Bellevue, Washington 98005, USA
}

\begin{abstract}
Sewage pollution is an increasing problem in tropical marine environments. In this review we synthesize present knowledge of the effects of sewage pollution on coral-reef communities, and suggest directions for future research. A wide range of sewage impacts on coral-reef communities has been reported. Little or no impact has been observed on some reefs in well-flushed waters that receive small quantities of effluent, whereas large discharges of effluent into poorly-flushed lagoons and bays have caused major changes in species composition and abundance. The 3 components of sewage effluent most detrimental to coral communities are nutrients, sediments, and toxic substances. Nutrient enrichment by sewage effluent may enhance benthic algal biomass and primary production in the water column. Increased primary production in the water column favors benthic filter-feeding invertebrates which, with the benthic algae, may out-compete corals and other reef-building organisms. Anthropogenic inputs of dissolved nutrients and organic particulate matter may also depress oxygen levels. While heavy sediment loads on corals may be lethal, lesser quantities may inhibit growth, cause changes in the growth forms of colonies, decrease coral cover, alter species composition of reef-building organisms, and inhibit coral recruitment. Toxic substances may induce metabolic changes in corals, decrease rates of growth and reproduction, or reduce viability of corals. Although further research is needed on all three major components of sewage effluent, the most critical need is for comprehensive, long-term studies of sewage impacts. The combined effects of particulate and toxic substances are especially poorly documented at this time.
\end{abstract}

\section{INTRODUCTION}

Sewage pollution of coral reefs has been recognized as a major environmental prablem for some time (e.g. Doty, 1969; Banner, 1974). Regions where sewage pollution of coral reefs has been documented include the Red Sea (Walker and Ormond, 1982), the wider Caribbean (Barnes, 1973; Rodriguez, 1981), Hawaii (Smith et al., 1981), and the Caroline Islands (Hardy and Hardy, 1972; Tsuda et al., 1975; Amesbury et al., 1976). The problem is more prevalent than these few accounts would indicate, since it is infrequently reported (Hardy and Hardy, 1972). This review synthesizes present knowledge of sewage pollution effects on coral-reef ecosystems, identifies problems of special concern, and suggests directions for future research.

Coral-reef ecosystems are extremely sensitive to environmental perturbations. This high sensitivity is linked to 3 factors. First, corals have narrow physiolog- ical tolerance ranges for environmental conditions (Johannes, 1975; Endean, 1976). Any variation of physical-chemical conditions outside these narrow tolerance ranges could be detrimental to coral growth and survival (Johannes and Betzer, 1975; Endean, 1976; Pearson, 1981). Second, the interactions of key reef species (e.g. plant-herbivore relations, algae-coral competition) are susceptible to pollutant stresses (Johannes and Betzer, 1975). The destruction of hermatypic corals by pollution leads to the eventual demise of many reef species dependent on living corals for food, shelter, and refuge from predators (Johannes, 1975). Lastly, the effects of toxic substances may be enhanced at high water temperatures common in coral reef environments (Johannes and Betzer, 1975). Documented effects of high temperatures include increased solubility, faster biotic uptake, and greater toxicity.

The potential impacts of sewage effluent on coral- 
reef communities may be classified into 3 broad categories representing separate but interacting processes: nutrient enrichment, sedimentation, and toxicity. In the first section of this paper, we discuss case histories of sewage pollution in coral-reef systems. Next, the effects of nutrient enrichment, sedimentation, and toxicity are discussed individually to provide a better understanding of the mechanisms producing different kinds of impacts. After a brief consideration of coral-reef recovery from disturbance, our current understanding of sewage pollution in relation to coral reefs is discussed, and areas for further research are suggested.

\section{CASE HISTORIES}

Most field studies investigating sewage-pollution effects on coral-reef ecosystems have been short-term and limited in scope. In addition, some studies have been poorly designed, thereby limiting the reliability of the data. One sewage-stressed reef ecosystem has been studied through time and merits extensive discussion: Kaneohe Bay, Oahu, Hawaii. Kaneohe Bay will be discussed in detail after the pertinent findings of short-term studies are reviewed.

\section{Short-term studies}

Increased abundances of benthic algae and filterfeeding invertebrates other than corals have been observed in several reef ecosystems subjected to chronic sewage pollution: e.g. Gulf of Aqaba, Red Sea (Walker and Ormond, 1982), offshore from Waianae, Oahu, Hawaii (Reed et al., 1977), and Mamala Bay, Hawaii (Dollar, 1980). Barnes (1973) observed evidence of chemical stress, nutrient enrichment, solids deposition, and bacterial contamination on coral reefs subjected to low volumes of sewage effluent from small hotels in Jamaica. The most common response to sewage loading was an increase in benthic algae and filter-feeding invertebrates such as bryozoans, sponges, and tunicates, with a corresponding decrease in the diversity and abundance of hermatypic corals.

The fringing reef near Aqaba, Jordan, is affected by a sewage discharge (primary treatment; unknown flow) and by sediment deposition from an apatite ore loading facility. Although the relative importance of sewage pollution and apatite loss from ships was not determined, spatial effects of the sewage discharge were apparent. An increase in algal cover (species of Ulva and Enteromorpha), a decrease in coral diversity, and an increase in small grazing molluscs were obvi- ous' from $5 \mathrm{~m}$ 'upstream' to $50 \mathrm{~m}$ 'downstream' of the outfall (Walker and Ormond, 1982). Walker and Ormond (1982) found that the death rate of coral tissue near the outfall was 4 to 5 times the death rate observed in a control area. Mortality may have been related to inhibition of calcification by high phosphate concentration, to stress caused by high sediment loads, or to localized bacterial infection triggered by the sewage effluent (Walker and Ormond, 1982). Dead portions of colonies were covered with filamentous algae, which trapped sediment and further stressed adjacent coral tissues. Stylophora pistillata, a fastgrowing opportunistic species (Loya, 1976a), was the only remaining abundant coral species.

Few substantial effects of sewage on coral reef communities have been demonstrated in well-flushed waters along open coasts. Reed et al. (1977) observed enhanced abundances of frondose algae near the outfall diffuser at Waianae, Oahu, Hawaii, but the distributions and abundances of corals, fishes, and small molluscs were not noticeably affected by the $4.5 \times 10^{3}$ $\mathrm{m}^{3} \mathrm{~d}^{-1}$ discharge. In a similar study conducted by Russo et al. (1979) off Mokapu, Oahu, coral coverage and algal biomass appeared unaffected within the first year of sewage discharge $\left(3.7 \times 10^{4} \mathrm{~m}^{3} \mathrm{~d}^{-1}\right.$ of primary treated sewage effluent). However, other biological changes were observed near the outfall and attributed to the discharge, including increased diversity and abundance of fishes, increased abundance of filterfeeding bryozoans, increased abundance of small molluscs, and changes in the abundances of key species and small molluscs. Short-term studies conducted within a year after initiation of small sewage discharges, i.e. effluent flows less than about $1.9 \times 10^{4}$ $\mathrm{m}^{3} \mathrm{~d}^{-1}$, have revealed little or no damage to coral reef communities (e.g. Tsuda et al., 1975). These data suggest that although algal populations increase rapidly in response to sewage enrichment, community-level impacts on corals may require a year or more to develop after the discharge begins.

\section{Kaneohe Bay, Hawaii}

The effects of sewage enrichment on coral-reef communities in Kaneohe Bay and their initial recovery following diversion of wastewaters are particularly well documented (Maragos and Chave, 1973; Banner, 1974; Laws and Redalje, 1979, 1982; Smith et al., 1981). Kaneohe Bay received major sewage inputs for about 30 yr (Laws, 1981). Sewage discharge rates increased from about $5.7 \times 10^{3}$ to $3.2 \times 10^{4} \mathrm{~m}^{3} \mathrm{~d}^{-1}$ between 1950 and 1977 , with most of the wastewaters receiving secondary treatment after 1963. In 1977 and 1978, wastewaters from the Kailua-Kaneohe and Marine Corps 
treatment plants were diverted to an open ocean outfall off Mokapu Point (Fig. 1).

\section{Sewage impacts}

As a consequence of nutrient enrichment by sewage discharges into southern Kaneohe Bay, phytoplankton biomass and total primary productivity were enhanced, and water clarity was reduced (Laws and Redalje, 1979; Smith et al,, 1981). For example, the average chlorophyll a concentration near the outfall (OF sector in Fig. 1) was 6.7 times the average value for

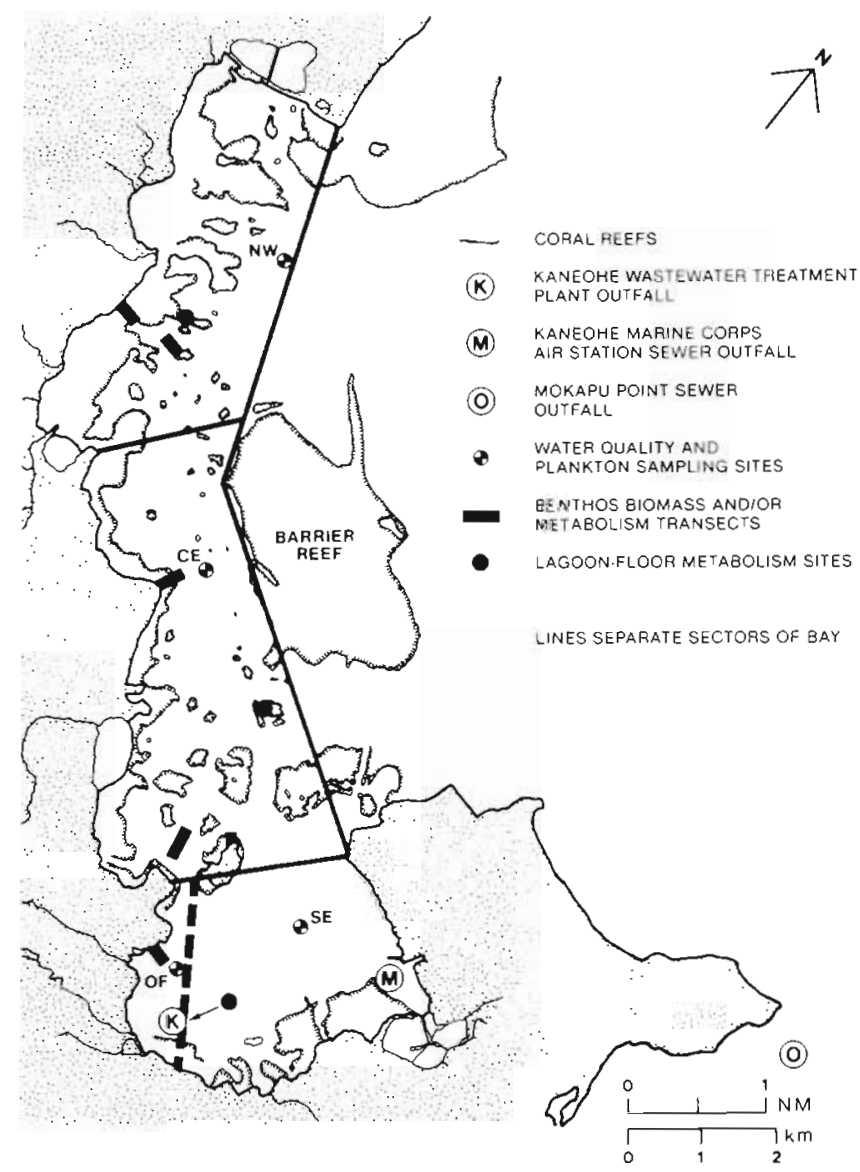

Fig. 1. Locations of coral reefs, prediversion sampling stations, and postdiversion sampling stations in Kaneohe Bay, Hawaii (adapted from Smith et al., 1981)

the central (CE) and northwest (NW) sectors combined (Caperon et al., 1976; Laws and Redalje, 1979; Smith et al., 1981). Other water-quality variables, including dissolved oxygen and inorganic nitrogen, showed either little change with distance from the sewage outfalls or little response to sewage diversion. Inorganic nitrogen levels were insensitive to sewage loading because of rapid uptake in a nitrogen-limited system (Laws and Redalje, 1979, 1982; Smith et al., 1981).
Benthic communities in Kaneohe Bay were affected by sewage effluent in several ways. Coral cover, taxonomic richness, and net calcification rates decreased (Banner, 1974; Kinsey, 1979; Smith et al., 1981). Biomass of the algae Ulva and Hydroclathrus increased in the OF and SE sectors, and biomass of the bubble alga Dictyosphaeria cavernosa increased in the CE sector (Soegiarto, 1973; Banner, 1974; Smith et al., 1981). In general, benthic community structure shifted away from corals and coral associates toward filter feeders, such as sponges and zoanthids (Maragos, 1972; Smith et al., 1981). Sewage influenced the coral reefs of central Kaneohe Bay indirectly by stimulating the growth of Dictyosphaeria cavernosa (Smith et al., 1981). This green bubble alga kills corals (especially Porites compressa) by forming thick mats which smother all underlying reef organisms (Maragos and Chave, 1973; Banner, 1974). D. cavernosa failed to dominate benthic communities in the northwest sector, possibly because of more intense grazing pressure and better flushing there (Maragos, pers. comm.). Living corals transplanted to the south bay were quickly outcompeted by tunicates, bryozoans, sponges, sabellid worms, and other filter-feeders (Maragos, 1972). Maragos (1972) observed that the survival time of transplanted corals was directly proportional to distance from the sewage outfalls. Sorokin (1973) found that sulfide levels in the sediments increased, and the

Table 1. Responses of ecosystem variables to sewage diversion.

\begin{tabular}{|c|c|}
\hline Group & $\begin{array}{c}\text { Intensity of response and magnitude } \\
\text { of spatial gradient }\end{array}$ \\
\hline \multirow[t]{2}{*}{1} & $\begin{array}{l}\text { Moderate response to sewage diversion, } \\
\text { Moderate spatial gradient }\end{array}$ \\
\hline & $\begin{array}{l}\text { Dissolved inorganic nitrogen } \\
\text { Particulate organic carbon } \\
\text { Phytoplankton biomass } \\
\text { Phytoplankton growth rate } \\
\text { Phytoplankton dry weight } \\
\text { Lagoon floor nitrogen release } \\
\text { Extinction coefficient }\end{array}$ \\
\hline \multirow[t]{2}{*}{2} & $\begin{array}{l}\text { Large response to diversion, } \\
\text { Wide range of spatial gradients }\end{array}$ \\
\hline & $\begin{array}{l}\text { Dissolved inorganic phosphorus } \\
\text { Hard bottom algal biomass } \\
\text { Hard bottom cryptofaunal biomass } \\
\text { Lagoon floor biomass }\end{array}$ \\
\hline 3 & $\begin{array}{l}\text { Slight response to diversion, } \\
\text { Small to large north-south gradient }\end{array}$ \\
\hline & $\begin{array}{l}\text { Detritus } \\
\text { Zooplankton structure } \\
\text { Benthic algal structure } \\
\text { Benthic macrofauna structure } \\
\text { Fish structure }\end{array}$ \\
\hline
\end{tabular}


anaerobic layer expanded closer to the Kaneohe sewage outfall, suggesting that a toxic effect contributed to the demise of corals and the absence of Dictyosphaeria in the southern basin. Low levels of available light probably restricted the growth of Dictyosphaeria in the southern basin as well (Smith et al., 1981; Maragos, pers. comm.).

Fish communities on reef slopes and crests exhibited substantial differences among the various sectors of Kaneohe Bay. By the late 1970s, planktivorous species such as Stolephorus purpureus and Pranesus insularum dominated the fish communities of the outfall sector and the central sector (Clarke, 1973; Brock et al., 1979). This contrasts with other reefs, which are generally dominated by predators (Goldman and Talbot, 1976). Six species resided in the southern basin compared with 43 species in the central sector and 40 species in the northern sector (Smith et al., 1981). Presumably, this pattern resulted from the absence of living corals and reduced habitat complexity of the southern sector.

\section{Recovery after sewage diversion}

Smith et al. (1981) studied the responses of physical, chemical, and biological variables to sewage diversion. These variables fell into 3 response categories depending on the degree of change from the prediversion period (Jan, 1976, through Nov, 1977) to the postdiversion period (Dec, 1977, through Aug, 1979) and the magnitude of a north-south spatial gradient (Table 1). Particulate and dissolved inorganic materials, phytoplankton, and microheterotrophic masses in Group 1 exhibited gradients from high values near the outfall to low values in the northern basin (Smith et al., 1981). These parameters decreased rapidly within 1 to 2 yr following sewage diversion, possibly returning to baseline values (Smith et al., 1981). However, Laws (1981) and Laws and Redalje (1982) suggested that nutrients released from organic-rich sediments may have continued to support chlorophyll a biomass and nutrient levels above baseline values throughout the postdiversion period.

The second group of variables, including dissolved inorganic phosphorus and several benthic biomass measures, showed a large decrease after sewage diversion. The large responses of benthic biomass variables reflect the decreased influx of particulate matter to the benthos, compared with that contributed previously from a water column enriched with sewage nutrients. However, Smith et al. (1981) reported that benthic conditions at the end of their postdiversion survey did not match the 'presewage' baseline.

The third group of variables showed little response to sewage diversion. The slight change in community structure variables from prediversion to postdiversion periods indicates that benthic communities did not have sufficient time to return to a predischarge condition (Smith et al., 1981). Disintegration of reef rock, which was linked to shifts in reef community metabolism, could account for a delay in recovery. Moreover, slow recruitment by most coral populations precludes rapid succession and recovery of reef communities. By mid 1981, partial recovery of the coral communities was evident (Smith et al., 1981). As of July 1983, coral coverage had increased substantially in the previously impacted portions of Kaneohe Bay (Maragos, pers. comm.). The pollution-sensitive coral species Pocillopora damicomis has recently invaded the southem basin, where only relatively tolerant species of Montipora and Porites were found during the sewage discharge period, e.g. in the 1971 survey of Maragos (1972).

\section{MECHANISMS OF SEWAGE IMPACTS ON CORAL REEFS}

\section{Nutrient enrichment}

Nutrient enrichment of coral-reef communities produces a variety of direct and indirect effects. At low levels of nutrient input, primary production of benthic algae is enhanced without affecting biomass, species composition, or trophic structure (Kinsey and Domm, 1974). Moderate levels of enrichment cause increased primary production and biomass in both phytoplankton and benthic algal populations (Laws and Redalje, 1979; Smith et al., 1981). With increasing nutrient inputs, shifts in species dominance often lead to blooms of nuisance algae, especially planktonic flagellates (Clutter, 1972; Mahoney and McLaughlin, 1977) and benthic green or blue-green algae (Banner, 1974; Snedaker, pers. comm.). Some opportunistic algae are extremely sensitive to nutrient enrichment. For example, the green bubble alga Dictyosphaeria cavernosa responded to sewage inputs at distances of over $10 \mathrm{~km}$ from the outfalls in Kaneohe Bay (Banner, 1974). Although enhanced plant growth and sewage particles around outfalls often attract grazing fishes (Johannes, 1975; Russo, 1982), algal blooms may persist even in the presence of enhanced grazer populations (Walker and Ormond, 1982).

Through its effects on production and biomass of algae, moderate nutrient enrichment often influences coral communities indirectly. Elevated phytoplankton populations may stress hermatypic corals in two ways. First, reduced light penetration affects coral nutrition, growth, and survival through negative impacts on the zooxanthellae (Smith et al., 1981). Second, increased 
water-column production often favors the growth of benthic filter-feeders such as sponges, bryozoans, and tunicates, which outcompete corals for space (Maragos, 1972; Maragos and Chave, 1973; Birkeland 1977). The biomass of hard-bottom cryptofauna may also increase (Brock and Smith, 1983). As benthic algae increase in biomass, they colonize coral skeletons, overgrow living corals, and form thick mats which kill all underlying organisms by blocking light and trapping sediment (Maragos and Chave, 1973; Banner, 1974; Walker and Ormond, 1982). Opportunistic coral species such as Stylophora pistillata may also dominate or replace other corals (Loya, 1976a; Walker and Ormond, 1982). Finally, bacterial populations in coral mucus may increase and kill coral tissue (Mitchell and Chet, 1975). As a result of one or more of these indirect effects, heterotrophic processes overwhelm autotrophic production and calcification, resulting in a net erosion of the reefs (Kinsey, 1979).

Extremely high nutrient inputs exert additional stress on reef-building organisms by promoting sedimentation and toxicity. High nutrient loading enhances planktonic primary production and leads to increased sedimentation of organic material, as was observed in Kaneohe Bay (Smith et al., 1981). High phosphate levels also inhibit calcification by corals and coralline algae (Kinsey and Davies, 1979).

The responses of coral communities to natural variations in nutrient loading provide interesting comparisons with enrichment effects from sewage effluent. Birkeland (1977) described the effects of natural nutrient inputs by upwelling on coral-reef communities off the Pacific coast of Panama. With a rich supply of nutrients, fouling organisms such as filamentous algae, bryozoans, and tunicates rapidly colonize open substrate and overgrow most coral recruits. As nutrient and light levels decrease, the rate of biomass accumulation on benthic substrates declines, and hermatypic corals have a better chance of reaching a size large enough to avoid being overgrown. Thus, moderate sewage inputs may mimic nutrient enrichment from natural upwelling by promoting rapid growth of benthic organisms, high biomass of filamentous algae, low diversity of corals, and domination by benthic filter-feeders.

The relative importance of direct and indirect effects of nutrient enrichment on coral reefs probably varies with reef type and reef trophic status. In nutrient-poor regions, anthropogenic nutrient inputs may cause profound shifts in community structure by reducing the importance of corals and increasing the importance of r-selected filter-feeders. In upwelling areas such as the eastern Pacific, moderate sewage inputs may be less likely to cause dramatic changes since reef biota are already adapted to nutrient perturbations.

\section{Sedimentation}

Suspended solids in receiving waters for sewage discharges originate from 3 sources: particles contained in effluents, particulate organic matter produced by nutrient enrichment, and natural seston. The relative importance of these sources depends on wastewater treatment level. Because quantitative measurements of solid deposition rates and sedimentation effects are unavailable for sewage discharges in coral reef environments, the following discussion emphasizes the sedimentation of particulate matter derived from terrestrial runoff, dredging and filling activities, and resuspension of bottom sediments. It should be recognized, however, that the physical, chemical, and toxicological characteristics of sewage solids differ substantially from particulates derived from other sources.

Sediment rejection by corals and tolerance to sedimentation

Coral polyps reject sediment landing on the surface of the colony by 4 mechanisms: polyp distension by uptake of water through the stomodeum, tentacular movements, ciliary action, and mucus production (Marshall and Orr, 1931; Hubbard and Pocock, 1972). An efficient sediment-rejector like Montastrea cavernosa is capable of cleaning itself at deposition rates of up to about $14 \mathrm{mg} \mathrm{cm}^{-2} \mathrm{~d}^{-1}$ (Lasker, 1980). Average sedimentation rates measured over extended periods in natural coral reef habitats of the Caribbean range from 0.3 to $37 \mathrm{mg} \mathrm{cm}^{-2} \mathrm{~d}^{-1}$ (Griffin, 1974; Ott, 1975; Loya, 1976b; Lasker, 1980; Rogers, 1982, 1983). In the Indo-Pacific region, corresponding sedimentation values range from 0.1 to $228 \mathrm{mg} \mathrm{cm}^{-2} \mathrm{~d}^{-1}$ (Marshall and Orr, 1931; Smith and Jokiel, 1975; Schuhmacher, 1977; Randall and Birkeland, 1978). In shallow waters of both regions, higher sedimentation rates, which are beyond the upper ends of the quoted ranges, may be found.

The ability of corals to reject sediment is limited by several factors, such that a heavy coating of sediments or complete burial for more than several hours is lethal to most coral colonies (Edmondson, 1928; Marshall and Orr, 1931; Roy and Smith, 1971; Rogers, 1983). Studies by Hubbard and Pocock (1972) and Bak and Elgershuizen (1976) suggest that coral colonies are unable to coordinate transport of sediment off the colony by the shortest possible route. For those species in which removal is uncoordinated, the sediment rejection process is expected to be more efficient in small colonies than in large colonies (Dodge and Vaisnys, 1977). Second, silt $(<62 \mu)$ is the largest particle size effec- 
Table 2. Sensitivity of some common coral species to sedimentation

\begin{tabular}{|c|c|c|c|c|}
\hline \multirow[t]{2}{*}{ Species } & \multicolumn{3}{|c|}{ Sensitivity } & \multirow[t]{2}{*}{ Source } \\
\hline & Low & Moderate & High & \\
\hline Acropora cervicornis & & $\times$ & & Hubbard and Pocock (1972); Rogers (1983) \\
\hline Acropora corymbosa & & & $x$ & Bennett $(1971)^{\circ}$; Brown $(1972)^{\circ}$ \\
\hline Acropora hyacinthus & & & $\times$ & Bennett $(1971)^{\circ} ;$ Brown $(1972)^{\circ}$ \\
\hline Acropora palmata & & & $x$ & Rogers (1983) \\
\hline Other Acropora spp. & & $\times$ & & $\begin{array}{l}\text { Bennett (1971) }{ }^{\circ} \text { Brown }(1972)^{\circ} ; \text { Hubbard and Pocock (1972); } \\
\text { Ott (1975) }\end{array}$ \\
\hline Agaricia agaricites & & $x$ & & Bak $(1978)$ \\
\hline Diploria strigosa & $\times$ & & & Rogers (1983) \\
\hline Fungia spp. & $\times$ & & & Edmondson (1928); Marshall and Orr (1931) \\
\hline Madricis marabilis & & $x$ & & Bak (1978) \\
\hline Manicinia areolata & $x$ & & & Yonge (1935) \\
\hline Montastrea annularis & & $x$ & & Rogers (1983) \\
\hline Montastrea cavernosa & $x$ & & & Bak and Elgershuizen (1976); Lasker (1980); Loya (1976b) \\
\hline Pocillopora spp. & $\times$ & $x$ & & $\begin{array}{l}\text { Edmondson }(1928) \text {; Marshall and Orr }(1931) \text {; Bennett }(1971)^{\circ} \text {; } \\
\text { Brown }(1972)^{\circ}\end{array}$ \\
\hline Porites astreoides & & & $x$ & Bak $(1978)$ \\
\hline Other Porites spp. & $\times$ & $x$ & & $\begin{array}{l}\text { Edmondson (1928); Bennett }(1971)^{\circ} \text {; Brown }(1972)^{\circ} ; \\
\text { Hubbard and Pocock }(1972) \text {; Ott }(1975)\end{array}$ \\
\hline Siderastrea radians & $\times$ & & & Ott (1975); Loya (1976b) \\
\hline Siderastrea siderea & $\times$ & & & Bak and Elgershuizen (1976); Loya (1976b) \\
\hline
\end{tabular}

tively removed by many coral species (Hubbard and Pocock, 1972). Larger size fractions, which are removed by some species but not others, must be transported by polyp distension or tentacular movement rather than by relatively weak ciliary action.

Species sensitivities to sedimentation are determined by the sediment-trapping properties of the colony and the ability of individual polyps to reject settled materials. Horizontal plate-like colonies and massive growth forms present large, stable surfaces for the interception and retention of settling solids. Conversely, vertical plates and upright branching forms are less likely to retain sediments (Bak and Elgershuizen, 1976; Dryer and Logan, 1978; Rogers, 1983). Tall polyps and convex colonies are also less susceptible to sediment accumulation than are other growth forms (Lasker, 1980). Although the efficiency of sediment rejection has been related to skeletal geometry and polyp morphology, polyp behavior may supercede morphological limitations (Bak and Elgershuizen, 1976).

The relative sensitivities of some coral species to sedimentation are given in Table 2. The genera Acropora, Porites and Pocillopora illustrate the variation in rank which may occur among species within a genus. In general, coral species inhabiting the seaward margins of a reef are less tolerant of high sediment loads than species found in nearshore areas (Vaughan, 1916; Marshall and Orr, 1931; Stern and Stickle, 1978).

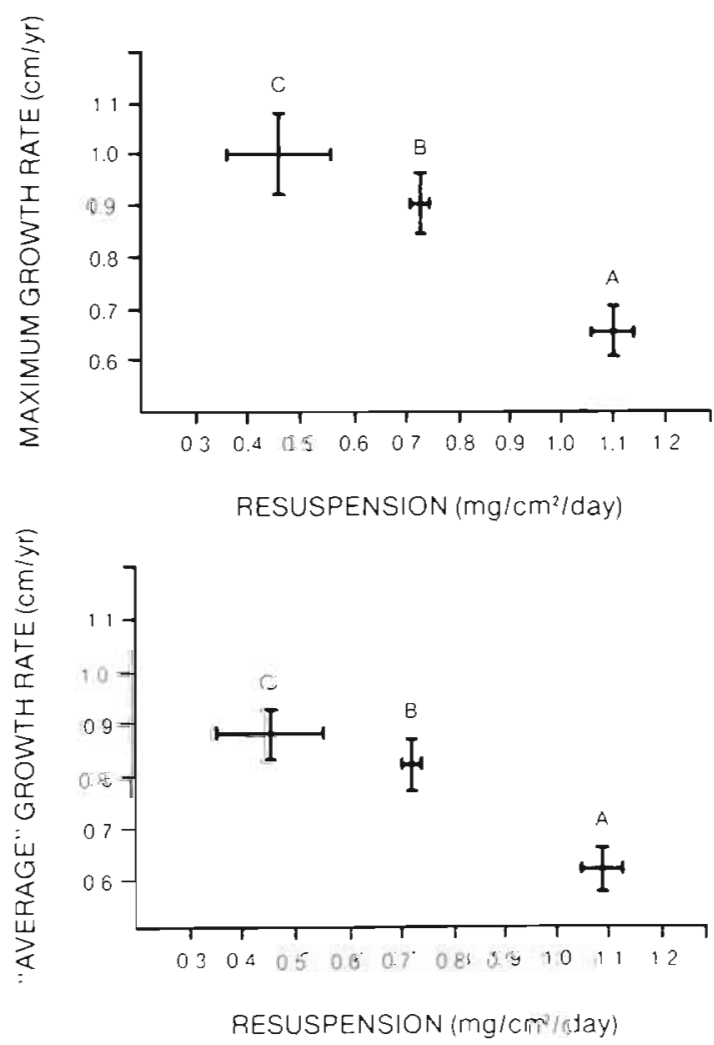

Fig. 2. Montastrea annularis. Growth rate in relation to sediment resuspension rate, Discovery Bay, Jamaica. Ranges given for resuspension values. Error bars for coral growth rate equal \pm 2 standard deviations. (After Aller and Dodge, 1974) 
Individual effects

High concentrations of suspended solids and rapid sedimentation may affect reef biota at the individual, population, and community levels. Sublethal sediment loads from either newly deposited sediments or resuspended sediments may affect coral colonies by decreasing growth rates, possibly leading to the death of all or part of the colony. In Discovery Bay, Jamaica, Aller and Dodge (1974) found that the average growth rate and the maximum growth rate of the coral Montastrea annularis were inversely proportional to sediment resuspension values (Fig. 2). The median particle size of resuspended material was less than $0.062 \mathrm{~mm}$. 'Resuspension values' also included fresh deposition, but Aller and Dodge (1974) showed that newly-deposited material was a minor component of the sediments collected in their traps. Increased sedimentation associated with a dredging operation conducted from 1941 to 1943 in Castle Harbor, Bermuda, was apparently responsible for decreased growth rates in corals (Dodge and Vaisnys, 1977). Impacts of substrate disruption persisted for several years after cessation of dredging, as a result of periodic sediment resuspension. Eventually, all corals older than $20 \mathrm{yr}$ died throughout the harbor.

Growth inhibition by sublethal sediment loads may be caused by decreased light availability, abrasion, and increased energy expenditure for sediment rejection. High turbidity interferes with light penetration to the bottom and thereby limits photosynthesis of zooxanthellae and, indirectly, coral growth (Roy and Smith, 1971; Maragos, 1972; Dallmeyer et al., 1982). Experimental additions of peat particles to field enclosures decreased primary production and reduced chlorophyll content by $22 \%$ in Montastrea annularis, indicating a loss of zooxanthellae from stressed corals (Dallmeyer et al., 1982). Calcification rates have been reduced as much as $40 \%$ by natural resuspension of sediments (Dodge et al, 1974), and as much as $33 \%$ by short-term dredging impacts (Bak, 1978).

Abrasion of coral surfaces by sediments or suspended particulates transported by wave surge may contribute to decreases in net rates of tissue growth and calcification (Johannes, 1975; Loya, 1976b; Rogers, 1983). Wiens (1962) concluded that mechanical scour plays a role in the natural destruction of coral reefs, particularly at the reef margins

Rejection of sediments by corals is energetically expensive. Dallmeyer et al. (1982) demonstrated a significant increase in coral respiration rates during vigorous sediment-cleansing activities. As energy required for sediment removal is diverted from other metabolic functions, growth and reproductive output may be reduced (Aller and Dodge, 1974; Dodge and
Vaisnys, 1977; Dallmeyer et al., 1982). Moreover, if coral polyps are occupied with sediment rejection activities, they may be unable to capture zooplankton effectively.

In addition to effects on coral growth rates, high sedimentation rates may modify colony growth towards forms more resistant to sedimentation (Marshall and Orr, 1931; Chappell, 1980). Roy and Smith (1971) concluded that reefs in the clear water areas of Fanning Atoll Lagoon were ecologically different from those in the turbid-water areas. Ramose corals, which intercept less sediment than massive corals of the same surface area, accounted for $55 \%$ of the individuals at the turbid site and only $10 \%$ of those in the clearwater area. Despite ecological differences, species composition in the 2 areas was similar, with only 4 species being excluded from the turbid-water area (Maragos et al., 1970).

In contrast to the relatively inert calcium carbonate sediments typical of reef environments, much of the particulate and dissolved organic matter discharged in sewage effluent is organic, and is readily decomposed by microbes in the water column or sediments. Because most tropical organisms, including corals, are living near their critical tolerance levels for dissolved oxygen (Kinsey, 1973), depressed oxygen levels caused by decomposition of sewage organics 'may constitute a significant stress' (Johannes, 1975). Depression is most critical at night when oxygen levels are usually at their daily minima. Kinsey (1973) indicated that reef communities maintained a constant rate of oxygen consumption (respiration) as ambient dissolved oxygen levels declined to zero in field experiments. However, isolated corals may decrease their respiration rates to survive short periods of anoxia (Yonge et al., 1932).

\section{Population and community effects}

At the population and community levels, increased sedimentation may inhibit population recruitment, cause changes in the relative abundances of coral species, reduce substrate cover by living corals, and reduce species richness (or diversity). Loya (1976b) examined two reefs at Negro-Bank, Puerto Rico, to determine the role of turbidity and sedimentation in control of community structure. Coral diversity and living cover were high at the upper East Reef where average water turbidity and sedimentation were low, but were relatively low at the West Reef where average turbidity and sedimentation were much higher (Fig. 3). The major source of sediment stress appeared to be periodic resuspension and redeposition of fine sediments during and after heavy seas. Species composi- 


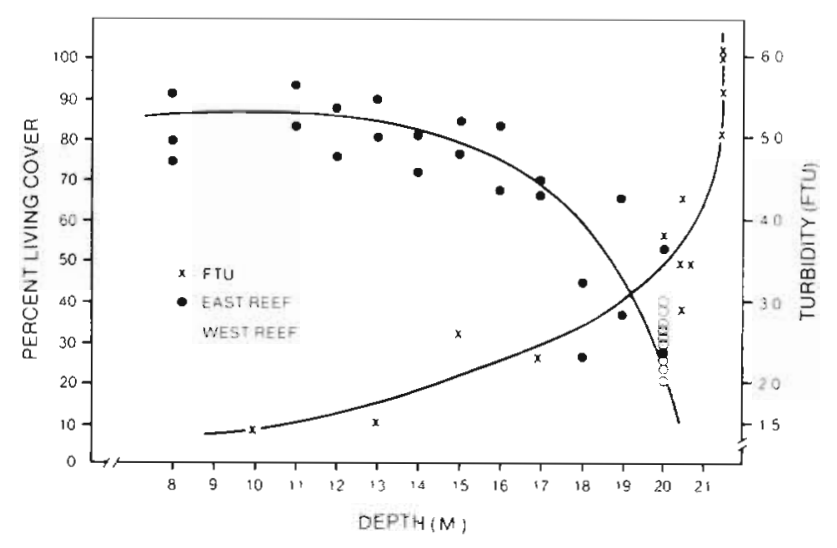

Fig. 3. Relations between percent living coral cover, turbidity, and water depth, Negro-Bank Reefs, Puerto Rico. (After Loya, 1976b)

tion and abundance were also influenced by the sedimentation patterns. A coral community resistant to sedimentation was identified at the West Reef, with Montastrea cavemosa, Siderastrea radians, S. sidera and Diploria strigosa being the most successful species. Although $M$. cavernosa was dominant at both reefs, $M$. annularis (the main framework-builder throughout the Caribbean) was considered abundant only at East Reef.

At Castle Harbor, Bermuda, Dodge and Vaisnys (1977) documented changes in community structure in response to increased sedimentation. As a result of the initial impact of dredging and an extended recolonization period, dominance in the coral community shifted from Diploria strigosa to D. labyrinthiformis. Hubbard and Pocock (1972) demonstrated that D. labyrinthiformis is more capable of sediment rejection than $D$. strigosa, at least for particles larger than fine sand.

Randall and Birkeland (1978) studied the effects of sedimentation on coral reefs in Fouha and Ylig Bays, Guam. In both bays, sedimentation rates were high near the river drainage at the head of the bay and low at the bay mouth. The species richness and percent cover of the coral communities generally increased along the shore-to-seaward gradient. Other environmental variables including temperature, $\mathrm{pH}$, salinity, nitrate, and phosphate showed no systematic variation among stations. Based on their data, Randall and Birkeland (1978) would expect a depauperate coral community of less than 10 species covering less than $2 \%$ of the solid substrate' where average sediment loads are about 160 to $220 \mathrm{mg} \mathrm{cm}^{-2} \mathrm{~d}^{-1}$. A 'rich coral community of over 100 species covering over $12 \%$ of the solid substrate' is expected where average sedimentation rates are about 5 to $32 \mathrm{mg} \mathrm{cm}^{-2} \mathrm{~d}^{-1}$.

Other studies indicate a wide variety of coral reef responses to anthropogenic sediment influx, from essentially no impact (Griffin, 1974; Sheppard, 1980;
Dollar and Grigg, 1981; Rogers, 1982) to widespread degradation of reef communities (Brock et al., 1965 , 1966; Marsh and Gordon, 1974). Given quantitative data, relations between coral response parameters and sedimentation rates may be inferred. Response curves calculated from the data of Randall and Birkeland (1978) are presented here to illustrate the functional dependence of coral community structure on the rate of sediment deposition (Fig. 4). Only data from upper slope communities were used to develop the curves in Fig. 4, since upper slope communities form the best developed reefs and are normally subjected to the least sedimentation relative to other coral habitats. Lines were fitted to the data using least-squares linear regression. Species richness, percent cover, and mean colony size of corals are each inversely related to sedimentation rate (Fig. 4).

The variability of coral community parameters changes along the gradient of sedimentation rates shown in Fig. 4. At sedimentation rates less than 40 to $50 \mathrm{mg} \mathrm{cm} \mathrm{cm}^{-2} \mathrm{~d}^{-1}$, the variances around the regression lines are relatively low. Since many corals on the upper reef slope flourish only where sedimentation is minimal, the low variability of species number and percent cover at sedimentation rates less than 40 to $50 \mathrm{mg} \mathrm{cm}^{-2} \mathrm{~d}^{-1}$ may reflect the control of community structure through biological mechanisms such as competition, predation, and mutualism. At the highest sedimentation rates of 150 to $250 \mathrm{mg} \mathrm{cm}^{-2} \mathrm{~d}^{-1}$, the low variance in community structure may reflect environmental stress. Only a few resistant species are able to survive extremely high sediment influx, and community structure is most likely controlled by physical variables rather than biological interactions. In the midrange of sedimentation values, both physical and biological mechanisms may be important in determining community structure, with moderate stress producing several alternative community structures. Thus, the variance in community structure is greatest at the midrange of sediment stress (50 to $150 \mathrm{mg} \mathrm{cm}^{-2} \mathrm{~d}^{-1}$ ).

Based on information in Randall and Birkeland (1978) and other accounts, a qualitative impact scale was developed for various levels of sediment deposition and effects on coral cornmunities (Table 3 ). Because limited data are available in the literature, the degree of impact assigned to each level of sediment deposition should be considered tentative.

\section{Toxicity}

Toxic effects on corals and other reef organisms may result from one or more of the chemicals commonly found in sewage effluent: e.g. PCBs, metals, chlorine, phosphate, pesticides, and petroleum hydrocarbons. 


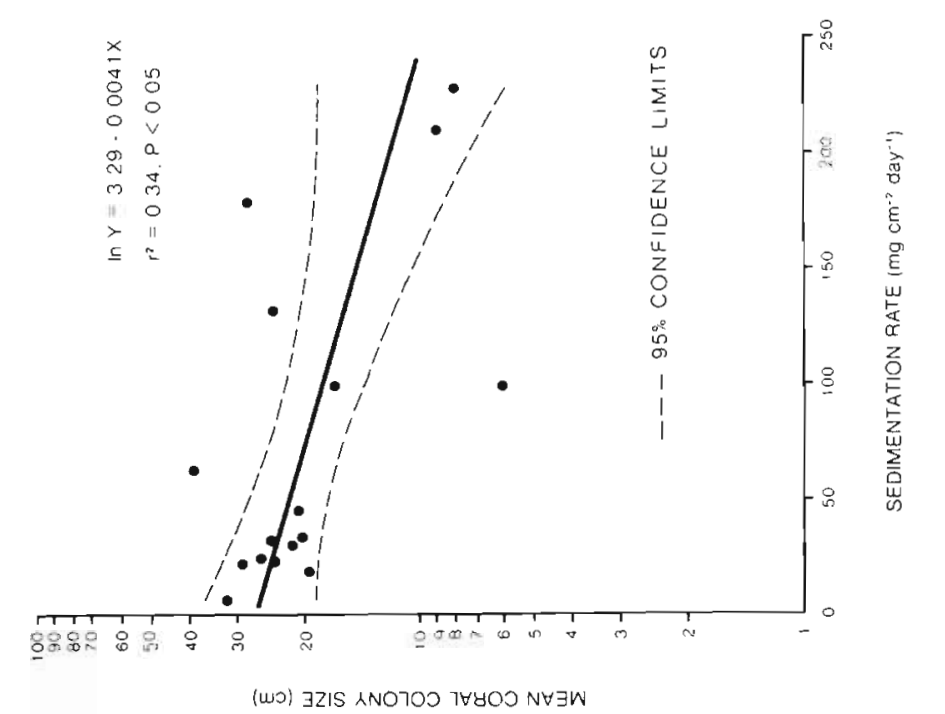

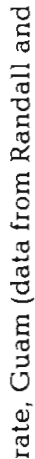
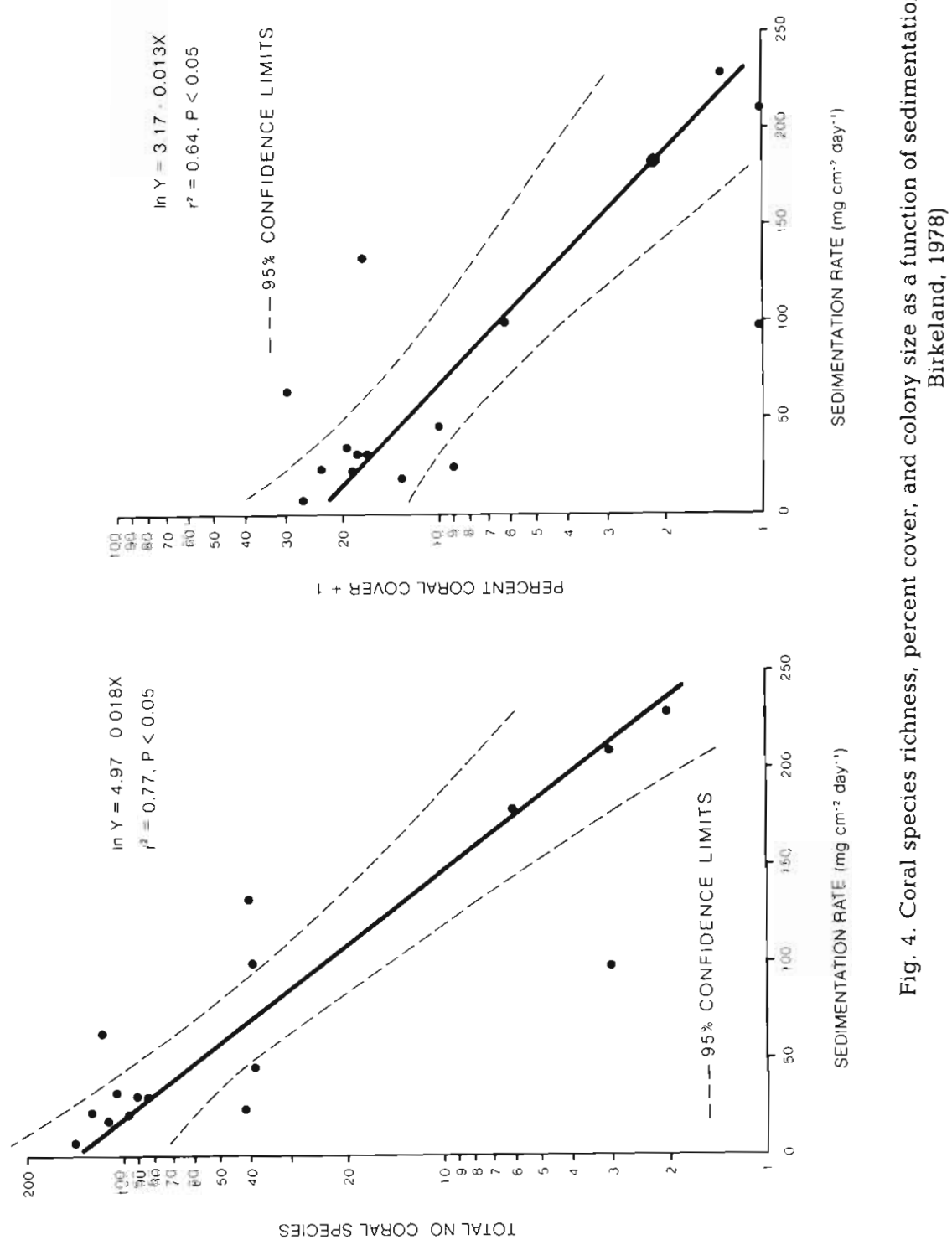
are not likely to be present in high concentrations, chronic exposure of reef organisms to low petroleum concentrations is of greater concern than acute toxic effects. Brief, low-level exposure to physically and chemically dispersed oil may elicit only temporary behavioral responses from coral colonies (Knap et al., 1983). Long-term studies have not yet been completed.

In addition to toxic substances in the sewage effluent, toxic substances in bottom sediments near sewage outfalls may also affect coral communities. Hydrogen sulfide in bottom sediments increases with proximity to sewage discharge sites as the organic content of the sediments increases (Sorokin, 1973). The release of toxic sulfides from bottom sediments may have been partly responsible for coral mortality and for the low diversity of reef communities in southern Kaneohe Bay (Maragos, 1972; Maragos and Chave, 1973). In some instances, resuspension of sediments during storms may also transfer toxic materials (e.g. PCBs, metals, pesticides) to the water column, increasing the likelihood of affecting reef biota.

Most studies of the effects of toxic substances on coral reef organisms have been short-term (e.g. less than $1 \mathrm{wk}$ ). Yet results of several studies of petroleum contamination suggest that sublethal and lethal effects may be delayed or prolonged in some cases. Whereas uptake of petroleum hydrocarbons by corals occurs relatively quickly, depuration does not. Peters et al. (1981) and Knap et al. (1982) reported that depuration of corals did not occur within 2 wk after cessation of exposure. Death of coral tissue following short-term exposure to Bunker $C$ oil also may not occur until two weeks after exposure (Birkeland et al., 1976). The length of time over which delayed effects of toxic substances on coral biota may occur, and the severity of those delayed effects, have yet to be established.

\section{RECOVERY FROM IMPACTS}

Rates of coral recolonization and recovery from environmental perturbations are influenced by many factors, including the kind of disturbance, species composition of the reef community, location of the damaged habitat, size of the disturbed patch, intensity and frequency of disturbance, availability of a reproductive 'seed' population, larval and adult dispersal capabilities, current patterns, availability of substrate for larval settlement, survival of larvae and adults, and productivity of the ecosystem. Because the importance of these and other factors varies among sites, recolonization and recovery times also vary.

Recovery time for a coral reef after disturbance may vary from a few years to decades. Recovery of coral reef communities from small, localized disturbances such as extreme low tides, red tides, low temperatures and moderate storm damage usually requires a decade or less (Loya, 1975; Smith, 1975; Yamaguchi, 1975; Endean, 1976; Loya, 1976c; Shinn, 1976; Pearson, 1981). Small perturbations may increase coral diversity through compensatory mortality of dominant forms (Porter, 1972; Connell, 1978), and may promote asexual reproduction by fragmentation and dispersal of branching forms such as Acropora palmata and $A$. cervicornis (Highsmith et al, 1980). Following severe damage (e.g. extensive storm damage, volcanic eruption, nuclear explosions, floods, dredging), hermatypic corals may exhibit negligible recolonization even after 20 to 30 yr (Stephenson et al., 1958; Stoddart, 1963, 1969; Grigg and Maragos, 1974; Johannes, 1975; Endean, 1976; Pearson, 1981). In some cases, extreme habitat modification may preclude complete recovery (Johannes, 1975; Endean, 1976; Pearson, 1981). Estimates of recovery times from damage by Acanthaster planci vary from a few years to decades (Pearson and Endean, 1969; Endean, 1971; Branham, 1973; Endean, 1973; Randall, 1973; Pearson, 1974; Endean, 1976; Colgan, 1981; Pearson, 1981), and are probably related to the extent of the damage inflicted and the ecological characteristics of the reef community.

Life history strategies of the dominant species and key trophic interactions influence the initial response to natural or anthropogenic perturbations, as well as the direction and timing of coral reef recovery (Loya, 1976a, c; Pearson, 1981; Highsmith, 1982; Porter et al., 1982). In general, recovery of coral reef communities may be fastest on the reef flat and shallow reef front, and slowest in the coral lagoon and seaward reef slope zones (Pearson, 1981). Recovery of exposed coral reefs which are dominated by early successional communities is usually more rapid than recovery of sheltered reefs where communities are closer to 'climax' associations (Grigg and Maragos, 1974), because frequent physical disturbance of exposed habitats favors opportunistic species (Loya, 1976a). Recovery of corals may be delayed if grazer populations are depressed, allowing space to be monopolized by benthic algae (Fishelson, 1973; Birkeland, 1977; Sammarco, 1982).

\section{DISCUSSION AND CONCLUSIONS}

Sewage effluent is potentially harmful to coral-reef communities. The degree to which reef communities are affected is determined primarily by the quantity and quality of effluent and the hydrography of the receiving waters. Whereas a small discharge into wellflushed waters may impact reef biota little or not at all, a large discharge may cause the disruption of community structure and the eventual erosion of the reef 
through mechanical, chemical, and biological processes.

In undisturbed habitats, coral reefs exhibit a wide range of individual and community responses along gradients of nutrient influx and sedimentation. This range of responses includes modification of coral growth forms and growth rates, and changes in species composition, diversity, and abundance of corals. The kinds of biological responses caused by low to moderate inputs of sewage effluent are similar to those found along a natural enrichment gradient. Slight nutrient enrichment by sewage effluent may stimulate marine productivity, and outfall structures may provide additional habitat for reef biota. Although these changes may be viewed as beneficial, other effects of sewage discharges on reef biota have not been fully documented. For example, subtle changes in reef ecology which may accompany the discharge of toxic substances in sewage effluent warrant further investigation.

Healthy coral communities may exist in chronically turbid waters, especially when strong currents prevent the build-up of sediments on coral surfaces (Marshall and Orr, 1931; Roy and Smith, 1971). Nevertheless, corals exposed to high turbidity or rapid sedimentation are less diverse and less abundant than those at unperturbed sites with clear water (Roy and Smith, 1971; Loya, 1976a; Randall and Birkeland, 1978). Since coral depth distribution is limited by light penetration, increased turbidity levels may produce an apparent shift of coral depth distributions toward shallower waters. The relation of species distributions to light levels is complex (Sheppard, 1982), and a simple response to elevated turbidity is unlikely. Unconsolidated substrates are also unsuitable for settlement and survival of coral recruits (Harrigan, 1972 as cited by Johannes, 1975). Therefore, accumulation of sediment on hard substrates inhibits larval settlement and juvenile coral development (Edmondson, 1928; Maragos, 1972; Dodge and Vaisnys, 1977). The effects of deposited sediments on coral recruits and adults may persist long after the source of primary sedimentation has been reduced or eliminated, due to the periodic resuspension of deposited materials.

Despite the large quantity of information available on the basic ecology of coral reefs, data on anthropogenic impacts are limited. Those studies which have been performed are, with the exception of Kaneohe Bay, short-term and limited in scope. Shortterm studies are capable of documenting impacts at a given point in time. They are incapable of relating changes in the level of impact to natural variation in the environment, or to variations in the quantity or quality of a chronic pollutant discharge such as sewage effluent. The relative importances of effluent compo- nents (i.e. nutrients, sediments, toxic substances) to observed impacts on reef biota are also difficult to determine in short-term studies. Comprehensive, longterm studies incorporating field surveys, field experiments, and laboratory experiments are needed to understand the relative importances of these factors, and to assess their additive, antagonistic, and synergistic effects. Long-term studies are also needed to document recovery times of reef organisms and communities from sewage impacts, and to understand the processes which mediate and promote recovery.

Among the 3 components of sewage effluent of concern to reef communities, nutrient enrichment and sedimentation have received most study. Unfortunately, most sediment studies have involved sediments from sources other than sewage effluent. These particles may differ considerably in their physical and chemical characteristics from sewage-derived particles, and may affect coral communities differently than do sewage-derived particles. Additional research is needed to assess the direct and indirect effects of sewage-derived particles on coral reef biota. Further research is also needed to assess the effects of toxic substances on reef biota. Except for petroleum hydrocarbons, the effects of toxic substances have been largely ignored, despite the potential for immediate and delayed impacts. Substantial progress in the ability to predict and minimize impacts could be made if it were understood why certain reef species were favored and other reef species were disfavored when subjected to nutrient enrichment, sedimentation, and toxicity from sewage discharges.

Acknowledgements. We thank T. C. Ginn, D. S. Becker, and L. G. Williams for commenting on drafts of this paper. We are also grateful to S. V. Smith, J. E. Maragos, and C. E. Birkeland for valuable reviews and discussions during preparation of an earlier report on which this paper is based. H. Lee provided initial regression analyses of sedimentation data. Portions of this work were supported by a contract to Tetra Tech. Inc., from the US Environmental Protection Agency.

\section{LITERATURE CITED}

Aller, R. C., Dodge, R. E. (1974). Animal-sediment relations in a tropical lagoon Discovery Bay, Jamaica. J. mar. Res. 32 : 209-232

Amesbury, S. S., Tsuda, R. T., Randall, R. H., Birkeland, C. E., Cushing, F. A. (1976). Limited current and underwater blological survey of the Donitsch Island sewer outfall site, Yap, western Caroline Islands. University of Guam Marine Laboratory, Technical Report No. 24

Bak, R. P. M. (1978). Lethal and sublethal effects of dredging on reef corals. Mar. Pollut. Bull. 9: 14-16

Bak, R. P. M., Elgershuizen, J. H. B. W. (1976). Patterns of oilsediment rejection in corals. Mar. Biol. 37: 105-113

Banner, A. H. (1974). Kaneohe Bay, Hawail: urban pollution and a coral reef ecosystem. Proc. 2nd Int. Symp. Coral Reefs, Brisbane 2: 685-702 
Barnes, E. S. (1973). Sewage pollution from tourist hotels in Jamaica. Mar. Pollut. Bull. 4: 102-105

Bennett, I. (1971). The Great Barrier Reef. Lansdowne, Melbourne, Australia

Best, B. R., Braley, R. D., Marsh, J. A., Jr., Matlock, D. B. (1981). Effect of chlorine on some coral reef phytoplankters and invertebrate larvae. Proc. 4th Int. Symp. Coral Reefs, Diliman, Quezon City 1: 169-172

Birkeland, C. (1977). The importance of rate of biomass accumulation in early successional stages of benthic communities to the survival of coral recruits. Proc. 3rd Int. Symp. Coral Reefs, Miami 2: 15-21

Birkeland, C., Reimer, A. A., Young, J. R. (1976). Survey of marine communities in Panama and experiments with oil. U.S. Environmental Protection Agency, Narragansett, Rhode Island, 600/3-76-028

Branham, J. M. (1973). The crown of thorns of coral reefs. Bioscience 23: 219-226

Brock, R. E., Smith, S. V. (1983). Response of coral reef cryptofaunal communities to food and space. Coral Reefs 1: $179-183$

Brock, R. E., Lewis, C., Wass, R. C. (1979). Stability and structure of a fish community on a coral patch reef in Hawaii. Mar. Biol. 54: 281-292

Brock, V. E., Jones, R. S., Helfrich, P. (1965). An ecological reconnaissance of Johnston Island and the effects of dredging. University of Hawaii, Hawaii Marine Laboratory, Technical Report No. 5

Brock, V. E., Van Heukelem, W., Helfrich, P. (1966). An ecological reconnaissance of Johnston Island and the effects of dredging. University of Hawaii, Institute of Marine Biology, Technical Report No. 11

Brown, T. W. (1972). Silt pollution - the destruction of Magnetic Island's coral fringing reefs (MS). Magnetic Island, Queensland, Australia

Caperon, J., Harvey, W. A., Steinhilper, E. A. (1976). Particulate organic carbon, nitrogen, and chlorophyll as measures of phytoplankton and detritus standing crops in Kaneohe Bay, Oahu, Hawaiian Islands. Pacif. Sci. 30: 317-327

Chappell, J. (1980). Coral morphology, diversity and reef growth. Nature, Lond. 286: 249-252

Clarke, T. A. (1973). Fishes of the open water. In: Smith, S. V., Chave, K. E., Kam, D. T. O. (ed.) Atlas of Kaneohe Bay: a reef ecosystem under stress. University of Hawaii Sea Grant Program, Honolulu, Hawaii, p. 99-100

Clutter, R. I. (1972). Subtle effects of pollution on inshore tropical plankton. In: Ruvio, M. (ed.) Marine pollution and sea life. Fishing News Books, Surrey, England, p. 435-439

Cohen, Y., Nissenbaum, A., Eisler, R. (1977). Effects of Iranian crude oil on the Red Sea octocoral Heteroxenia fuscescens. Environ. Pollut. 12: 173-186

Colgan, M. W. (1981). Long-term recovery process of a coral community after a catastrophic disturbance. University of Guam Marine Laboratory, Techn. Rep. No. 76

Connell, J. H. (1978). Diversity in tropical rainforests and coral reefs. Science, N. Y. 199: 1302-1310

Dallmeyer, D. G., Porter, J. W., Smith, G. J. (1982). Effects of particulate peat on the behavior and physiology of the Jamaican reef-building coral Montastrea annularis. Mar. Biol. 68: 229-233

Dodge, R. E., Vaisnys, J. R. (1977). Coral populations and growth patterns: responses to sedimentation and turbidity associated with dredging. J. mar. Res. 35: 715-730

Dodge, R. E., Aller, R. C., Thomson, J. (1974). Coral growth related to resuspension of bottom sediments. Nature, Lond. 247: $574-577$
Dollar, S. J. (1980). Ecological response of benthic communities to relaxation of sewage stress off Sand Island, Oahu. In: Environmental survey techniques for coastal water assessment, conference proceedings. University of Hawaii Sea Grant College Program and Water Resources Research Center, Honolulu, Hawaii, p. 113-151

Dollar, S. J., Grigg, R. W. (1981). Impact of a kaolin clay spill on a coral reef in Hawaii. Mar. Biol. 65: 269-276

Doty, M. S. (1969). The ecology of Honaunau Bay, Hawaii. University of Hawaii, Hawaii Botanical Science Paper No. 14

Dryer, S., Logan, A. (1978). Holocene reefs and sediments of Castle Harbour, Bermuda. J. mar. Res. 36: 399-425

Edmondson, C. H. (1928). The ecology of an Hawaiian coral reef. Bernice P. Bishop Museum Bull. No. 45

Eisler, R. (1975). Acute toxicities of crude oils and oil-dispersant mixtures to Red Sea fishes and invertebrates. Israel J. Zool. 24: 16-27

Endean, R. (1971). The recovery of coral reefs devastated by catastrophic events with particular reference to current Acanthaster planci plagues in the tropical Indo-West Pacific region. J. mar. biol. Ass. India 13: 1-13

Endean, R. (1973). Population explosions of Acanthaster planci and associated destruction of hermatypic corals in the Indo-West Pacific region. In: Jones, O. A., Endean, R. (ed.) Biology and geology of coral reefs, Vol. 2, Biol. 1. Academic Press, London, p. 389-438

Endean, R. (1976). Destruction and recovery of coral reef communities. In: Jones, O. A., Endean, R. (ed.) Biology and geology of coral reefs, Vol. 3, Biol. 2. Academic Press, London, p. 215-254

Fishelson, L. (1973). Ecology of coral reefs in the Gulf of Aqaba (Red Sea) influenced by pollution. Oecologia (Berl.) 12: 55-67

Fishelson, L. (1977). Stability and instability of marine ecosystems, illustrated by examples from the Red Sea. Helgoländer wiss. Meeresunters. 30: 18-29

Goldman, B., Talbot, F. H. (1976). Aspects of the ecology of coral reef fishes. In: Jones, O. A., Endean, R. (ed.) Biology and geology of coral reefs, Vol. 3, Biol. 2. Academic Press, London, p. 125-154

Griffin, G. M. (1974). Dredging in the Florida Keys. Case history of a typical dredge-fill project in the northern Florida Keys - effects on water clarity, sedimentation rates, and biota. Harbor Branch Foundation, Florida, Publ. No. 33

Grigg, R. W., Maragos, J. E. (1974). Recolonization of hermatypic corals on submerged lava flows in Hawaii. Ecology 55: $387-395$

Hardy, J. T., Hardy, S. A. (1972). Tidal circulation and sewage pollution in a tropical marine lagoon. Environ. Pollut. 3: 195-203

Highsmith, R. C. (1982). Reproduction by fragmentation in corals. Mar. Ecol. Prog. Ser. 7: 207-226

Highsmith, R. C., Riggs, A. C., D'Antonio, C. M. (1980). Survival of hurricane-generated coral fragments and a disturbance model of reef calcification/growth rates. Oecologia (Berl.) 46: 322-329

Hubbard, J. A. E. B., Pocock, Y. P. (1972). Sediment rejection by recent scleractinian corals: a key to palaeo-environmental reconstruction. Geol. Rdsch. 61: 598-626

Johannes, R. E. (1975). Pollution and degradation of coral reef communities. In: Ferguson Wood, E. J., Johannes, R. E (ed.) Tropical marine pollution. Elsevier, Amsterdam, p. 13-51

Johannes, R. E., Betzer, S. B. (1975). Introduction: marine communities respond differently to pollution in the tropics 
than at higher latitudes. In: Ferguson Wood, E. J., Johannes, R. E. (ed.) Tropical marine pollution. Elsevier, Amsterdam, p. 1-12

Kinsey, D. W. (1973). Small-scale experiments to determine the effects of crude oil films on gas exchange over the coral back-reef at Heron Island. Environ. Pollut. 4: $167-182$

Kinsey, D. W. (1979). Carbon turnover and accumulation by coral reefs. Ph. D. thesis, University of Hawaii, Honolulu

Kinsey, D. W., Davies, P. J. (1979). Effects of elevated nitrogen and phosphorus on coral reef growth. Limnol. Oceanogr. 24: $935-940$

Kinsey, D. W., Domm, A. (1974). Effects of fertilization on a coral reef environment - primary production studies. Proc. 2nd Int. Symp. Coral Reefs, Brisbane 1: 49-66

Knap, A. H., Solbakken, J. E., Dodge, R. E., Sleeter, T. D., Wyers, S. J., Palmork, K. H. (1982). Accumulation and elimination of $\left(9-{ }^{14} \mathrm{C}\right)$ phenanthrene in the reef-building coral (Diploria strigosa). Bull. environ. Contam. Toxicol. 28: $281-284$

Knap, A. H., Sleeter, T. D., Dodge, R. E., Wyers, S. C., Frith, H. R., Smith, S. R. (1983). The effects of oil spills and dispersant use on corals, a review and multidisciplinary approach. Oil and Petrochemical Pollution 1: 157-169

Lasker, H. R. (1980). Sediment rejection by reef corals: the roles of behavior and morphology in Monastrea cavernosa (Linnaeus). J. exp. mar. Biol. Ecol. 47: 77-87

Laws, E. A. (1981). Aquatic pollution. John Wiley and Sons, New York

Laws, E. A., Redalje, D. G. (1979). Effect of sewage enrichment on the phytoplankton population of a subtropical estuary. Pacif. Sci. 33: 129-144

Laws, E. A., Redalje, D. G. (1982). Sewage diversion effects on the water column of a subtropical estuary. Mar. environ. Res. 6: 265-279

Loya, Y. (1975). Possible effects of water pollution on the community structure of Red Sea corals. Mar. Biol. 29: $177-185$

Loya, Y. (1976a). The Red Sea coral Stylophora pistillata is an r strategist. Nature, Lond. 259: 478-480

Loya, Y. (1976b). Effects of water turbidity and sedimentation on the community structure of Puerto Rican corals. Bull. mar. Sci. 26: $450-466$

Loya, Y. (1976c). Recolonization of Red Sea corals affected by natural catastrophes and man-made perturbations. Ecology $57: 278-289$

Loya, Y., Rinkevich, B. (1979). Abortion effect in corals induced by oil pollution. Mar. Ecol. Prog. Ser. 1: 77-80

Loya, Y., Rinkevich, B. (1980). Effects of oil pollution on coral reef communities. Mar. Ecol. Prog. Ser. 3: 167-180

Mahoney, J. B،, McLaughlin, J. J. A. (1977). The association of phytoflagellate blooms in lower New York Bay with hypertrophication. J. exp. mar. Biol. Ecol. 28: 53-65

Maragos, J. E. (1972). A study of the ecology of Hawaiian reef corals. Ph. D. thesis, University of Hawaii, Honolulu

Maragos, J. E., Chave, K. E. (1973). Stress and interference of man in the bay. In: Smith, S. V., Chave, K. E., Kam, D. T O. (ed.) Atlas of Kaneohe Bay: a reef ecosystem under stress. University of Hawaii Sea Grant Program, Honolulu Hawaii, p. 119-123

Maragos, J. E., Roy, K. J., Smith, S. V. (1970). Corals from Fanning Island Lagoon. Hawaii Institute of Geophysics, University of Hawaii, Report No. 70-23

Marsh, J. A., Jr., Gordon, G. D. (1974). Marine environmental effects of dredging and power plant construction. University of Guam Marine Laboratory, Technical Report No. 8
Marshall, S. M., Orr, A. P. (1931). Sedimentation on Low Isles Reef and its relation to coral growth. Scient. Rep. Gt Barrier Reef Exped. 1: 94-133

McCloskey, L. R., Chesher, R. H. (1971). Effects of man-made pollution on the dynamics of coral reefs. In: Miller, J. W., Van Der Walker, J. G., Waller, R. A. (ed.) Scientists in the sea, Vol. 6. U.S. Department of the Interior, Washington, D.C., p. 229-237

Mitchell, R., Chet, I. (1975). Bacterial attack of corals in polluted seawater. Microb. Ecol. 2: 227-233

Morelock, J., Boulon, K., Galler, G. (1979). Sediment stress and coral reefs. In: Lopez, J. M. (ed.) Proceedings of the symposium on energy industry and the marine environment in Guayanilla Bay. Center for Energy and Environment Research, University of Puerto Rico and U. S. Department of Energy

Ott, B. (1975). Community patterns on a submerged barrier reef at Barbados, West Indies. Int. Revue ges. Hydrobiol. 60: 719-736

Pearson, R. G. (1974). Recolonization by hermatypic corals of reefs damaged by Acanthaster. Proc. 2nd Int. Symp. Coral Reefs, Brisbane 2: 207-215

Pearson, R. G. (1981). Recovery and recolonization of coral reefs. Mar. Ecol. Prog. Ser. 4: 105-122

Pearson, R. G., Endean, R. (1969). A preliminary study of the coral predator Acanthaster planci (L.) (Asteroidea) on the Great Barrier Reef. Fisheries Notes, Queensland Department Harbours and Marine 3: 27-55

Peters, E. C., Meyers, P. A., Yevich, P. P., Blake, N. J. (1981) Bioaccumulation and histopathological effects of oil on a stony coral. Mar. Pollut. Bull. 12: 333-339

Porter, J. W. (1972). Predation by Acanthaster and its effect on coral species diversity. Am. Nat. 106: 487-492

Porter, J. W., Battey, J. F., Smith, G. J. (1982). Perturbation and change in coral reef communities. Proc. natn. Acad Sci. U.S.A. 79: 1678-1681

Randall, R. H. (1973). Coral reef recovery following extensive damage by the 'crown-of-thorns' starfish Acanthaster placi (L.). Publ. Seto mar. biol. Lab. 20: 469-489

Randall, R. H., Birkeland, C. (1978). Guam's reefs and beaches. Part II: sedimentation studies at Fouha Bay and Ylig Bay. University of Guam Marine Laboratory, Techn. Rep. No. 47

Reed, A. S., Kay, E. A., Russo, A. R. (1977). Survey of benthic coral reef ecosystems, fish populations and micromolluscs in the vicinity of the Waianae sewage ocean outfall, Oahu, Hawaii - summer 1975. Water Resources Research Center University of Hawaii, Honolulu, Hawaii, Techn. Rep. No. 104

Rinkevich, B., Loya, Y. (1977). Harmful effects of chronic oil pollution on a Red Sea scleractinian coral population. Proc. 3rd Int. Symp. Coral Reefs, Miami 2: 585-591

Rinkevich, B., Loya, Y. (1979). Laboratory experiments on the effects of crude oil on the Red Sea coral Stylophora pistillata. Mar. Pollut. Bull. 10: 328-330

Rodriguez, A. (1981). Marine and coastal environmental stress in the wider Carbibbean region. Ambio 10: 283-294

Rogers, C. S. (1982). The marine environments of Brewers Bay, Perseverance Bay, Flat Cay and Saba Island, St. Thomas, U.S.V.I., with emphasis on coral reefs and seagrass beds, November 1978-July 1981. Department of Conservation and Cultural Affairs, Government of the Virgin Islands

Rogers, C. S. (1983). Sublethal and lethal effects of sediments applied to common Caribbean reef corals in the field. Mar. Pollut. Bull. 14: 378-382

Roy, K. J., Smith, S. V (1971). Sedimentation and coral reef 
development in turbid water: Fanning Lagoon. Pacif. Sci. 25: $234-248$

Russo, A. R. (1982). Temporal changes in fish community structure near a sewage ocean outfall, Mokapu, Oahu, Hawaii. Mar. environ. Res. 6: 83-98

Russo, A. R., Dollar, S. J., Kay, E. A. (1979). Ecological observations off the Mokapu, Oahu, ocean outfall: a post-installation study. Water Resources Research Center, University of Hawaii, Honolulu, Hawaii, Techn. Rep. No. 122

Sammarco, P. W. (1982). Echinoid grazing as a structuring force in coral communities: whole reef manipulations. J. exp. mar. Biol. Ecol. 61: 31-55

Schuhmacher, H. (1977). Ability in fungiid corals to overcome sedimentation. Proc. 3rd Int. Symp. Coral Reefs, Miami 1: 503-509

Sheppard. C. R. C. (1980). Coral fauna of Diego Garcia lagoon, following harbour construction. Mar. Pollut. Bull. 11: $227-230$

Sheppard, C. R. C. (1982). Coral populations on reef slopes and their major controls. Mar. Ecol. Prog. Ser. 7: 83-115

Shinn, E. A. (1976). Coral reef recovery in Florida and the Persian Gulf. Environ. Geol. 1: 241-254

Smith, G. B. (1975). The 1971 red tide and its impact on certain reef communities in the mid-eastern Gulf of Mexico. Environ. Lett. 9: 141-152

Smith, S. V., Jokiel, P. L. (1975). Water composition and biogeochemical gradients in the Canton Atoll lagoon: 2. budgets of phosphorous, nitrogen, carbon dioxide, and particulate materials. Mar. Sci. Communs 1: 165-207

Smith, S. V., Kimmerer, W. J., Laws, E. A., Brock, R. E., Walsh, T. W. (1981). Kaneohe Bay sewage diversion experiment: perspectives on ecosystem responses to nutritional perturbation. Pacif. Sci. 35: 279-402

Soegiarto, A. (1973). Benthic algae of the bay. In: Smith, S. V., Chave, K. E., Kam, D. T. O., Atlas of Kaneohe Bay: a reef ecosystem under stress. University of Hawaii Sea Grant Program, Honolulu, Hawaii, p. 67-90

Sorokin, Y. I. (1973). Role of microflora in the metabolism and productivity of Hawaiian reefs. Oceanology 13: 262-267
Stern, E. M., Stickle, W. B. (1978). Effects of turbidity and suspended material in aquatic environments. U.S. Army Engineer Waterways Experiment Station, Vicksburg, Mississippi, Techn. Rep. D-78-21

Stephenson, W., Endean, R., Bennett, I. (1958). An ecological survey of the marine fauna of Low Isles, Queensland. Aust. J. mar. Freshwat. Res. 9: 261-318

Stoddart, D. R. (1963). Effects of Hurricane Hattie on the British Honduras reefs and cays, October 30-31, 1961. Atoll Res. Bull. 95: 1-142

Stoddart, D. R. (1969). Post-hurricane changes on the British Honduras reefs and cays: resurvey of 1965. Atoll Res. Bull. 131: 1-25

Tsuda, R. T., Amesbury, S. S., Moras, S. C., Beeman, P. P. (1975). Limited current and underwater biological survey at the Point Gabert wastewater outfall on Moen, Truk. University of Guam Marine Laboratory, Techn. Rep. No. 20

Vaughan, T. W. (1916). The results of investigations of the ecology of the Floridian and Bahaman shoal-water corals. PIoc. natn. Acad. Sci. U.S.A. 2: 95-100

Walker, D. I., Ormond, R. F. G. (1982). Coral death from sewage and phosphate pollution at Aqaba, Red Sea. Mar. Pollut. Bull. 13: 21-25

Wiens, H. (1962). Atoll environment and ecology. Yale University Press, New Haven

Yamaguchi, M. (1975). Sea level fluctuations and mass mortalities of reef animals in Guam, Mariana Islands. Micronesica 11: 227-243

Yonge, C. M. (1935). Studies on the biology of Tortugas corals. 1. Observations on Maeandra areolata Linn. Carnegie Institute of Washington, Publication No, 452, 29: $185-198$

Yonge, C. M., Yonge, M. J., Nicholls, A. G. (1932). Studies on the physiology of corals VI. The relationship between respiration in corals and production of oxygen by their zooxanthellae. Scient. Rep. Gt Barrier Reef Exped. 1: 213-251

This review was submitted to the editor; it was accepted for printing on September 14, 1984 